\title{
Production and Marketing Problems of Papaya growers in North Karnataka
}

\author{
Dr. Hemambara, H. S.* and Mr. Yogesh, M. S. ** \\ *Subject Matter Specialist (ATMA Project) Agricultural Department Ramanagaram, Karnataka, India \\ **Research Scholar, Agribusiness Management, Institute of Development Studies, University of Mysore, Mysore \\ - 06, Karnataka, India
}

\begin{abstract}
Karnataka state, papaya crop occupied an area of 4889 ha and cultivated in 26 districts, out of which 2271 ha area is in northern parts of Karnataka state. In North Karnataka, Gulbarga and Bidar account for 56 per cent of area. However, in recent years papaya growers are facing several production and marketing problems. The problems in production includes non-availability of genuine plant material, high incidence of disease especially viral diseases, etc., have threatened the cultivation of papaya. The present study covers the economics of production and marketing of papaya and identify the problems faced by the papaya cultivator in its cultivation and marketing. It envisages to suggest possible corrective measure to bring about the desired improvement in production and marketing of papaya.
\end{abstract}

Keywords: Karnataka, Marketing, Papaya, Production,

\section{Introduction}

Karnataka is one of the progressive states of India with great potential development for fruit crops. The state is blessed with ten agro-climatic regions suitable for growing variety of fruits all around the year in Karnataka. The total area under fruit crops has increased from 2.60 lakh hectares in 2006-07, in 3.69 lakh hectares in 2011-12. The production of fruit crops has also gone up from 41.65 lakh lakh tonnes during 2006-07 to 63.17 lakh tonnes in 2011-12. The major districts growing fruit crops in the state are Kolar, Belgaum, Bidar, Bangalore, Bijapur, Gulbarga, Dharwad, Mysore, Tumkur, Bagalkot and Chitradurga. Papaya belongs to the genus Caricaof the family Caricaceae with 48 species of all the species Carica papaya L. is the most important and best known. It is cultivated all over the world. The original home of papaya is Tropical America. It has been reviewed by Schroeder (1958), where archaeological, historical and biological information have been used to pin point the possible origin of papaya (Singh, 1990). The Dutch Traveller Linschoten in 1598 described fruit brought from the Philippines to Malaya and hence to India.

The importance of papaya to agricultural and the world's economy is demonstrated by its wide distribution. It has long been known and cultivated in the home garden by the people of tropics, because it is one of the few fruits which fruit throughout the year, givesquick returns and adopts itself to diverse soil and climatic condition. It has emerged from the status of a home garden crop to that of commercial orchards in many tropical countries. It is one of the highest producer of fruits per ha. Papaya is cultivated over 30 countries of the world. The total planted area under papaya in the world is not known but its annual production has been estimated of approximately 16,00,000 metric tons. The major papaya producing region are Asia, South America, North Central America and Africa, Asia and South America produce about 65 per cent of the world production. Another 35 per cent is produced by north Central America and Africa (Singh, 1990). Papaya in India is grown as table purpose fruit and for the extraction of papin and pectin on a limited scale. India stands most important producer of the commodity followed by Mexico and Indonesia. According to 1990-91 estimates about 45,239 ha area in India is covered under papaya with a production of about 8,05,342 metric tons. Area of concentration are found in the states of Kerala, Karnataka, Orissa, West Bengal, Assam and Gujarat. Some of the popular varieties of papaya grown in India are honey dew, Coorg honeydew, Washington, Pink flesh sweet, CO-1, CO-2, CO-3, CO-4, CO-5, CO-6, CO-7, Pusa delicious, pusa majesty, Pusa-joint, Pusa dwarf, Pusananha, Pant-I, HPSC-3, Surya and Thaiwan-786.Thaiwan is one of the finest varieties of Indian papayas. The plants are of medium height $(180-220 \mathrm{~cm})$. Fruits are of medium to large size $(1-2 \mathrm{~kg})$ and oval in shape. The taste is superb with excellent quality. It is favourate for table purpose because of its taste Karnataka stood first in papaya production with annual production of 496.8 thousand metric tonnes.

\section{Objective}

1. To estimate growth in area, yield and production of papaya in Karnataka

2. To identify constraints in production and marketing of papaya and to suggest

appropriate policy measures. 


\section{Methodology}

Growth rate analysis was employed to know the growth rate in area, yield and production of papaya cultivation.North Karnataka was purposively selected for undertaking the study in Karnataka state. Random sampling procedure was adopted in the selection of the sample farmers from the study area. Papaya has been cultivated in twelve districts of north Karnataka region. However, the large scale cultivation of papaya was concentrated primarily in Gulbarga and Bidar districts. And from each district 50 sample farmers will be selected randomly thus forming a total sample size of 100 farmers. These districts were found to be agroclimatically homogeneous. Hence these 2 districts were specifically selected for the study.

\section{Results and Discussion}

1.1 Growth rates in area, production and productivity of papaya farming

1.2 Problems in production and marketing of papaya

1.1 Growth rates in area, production and productivity of papaya farming

Growth rates of area, production and productivity of papaya in Bidar and Gulbarga district as well as state as a whole for the period from 2001-02 to 2011-12 have been depicted in the Table 1.1. It was seen from the table that positive and significant growth in area and production were observed in the selected districts, whereas the growth rate with respect to state as a whole was positive in case of area and negative in case of production. And with respect to productivity the growth rate was negative for the selected districts as well as state as a whole.

Table 1.1 Growth rate of area, production and productivity of Papaya in study area (2001-02 to 2011-12)

\begin{tabular}{|c|l|c|c|c|}
\hline SL. No. & Particulars & \multicolumn{3}{|c|}{ Compound Growth Rate } \\
\hline & & Area & Production & Productivity \\
\hline 1 & Gulbarga & 12.43 & 29.43 & 2.28 \\
\hline 2 & Bidar & 8.78 & 11.62 & -2.90 \\
\hline
\end{tabular}

Source: National Horticulture Board Bangalore, 2013-14.

However, growth rates in area production and productivity of papaya in case of Gulbarga district were found to be highest. The corresponding figures were $12.43,29.43$ and -2.28 per cent respectively. Whereas Bidar district registered an growth rate of 8.78 per cent in case of area, 11.62 per cent in production and -2.90 per cent in case of productivity. On the contrary a lower growth rate were observed in case of state as a whole, which registered a positive growth rate of area $(0.80 \%)$ and negative growth rate of production $(-8.89 \%)$ and productivity $(-9.23 \%)$ of papaya.

\subsection{Problems in Production and Marketing of Papaya}

Opinion survey was conducted about the production and marketing constraints of papaya growers and the result have been presented in Table 1.2.

\subsubsection{Problems in papaya production}

From the Table 1.2 it could be observed that all the papaya growing sample farmers expressed the severity of virus attack along with labour intensiveness and water scarcity during papaya cultivation. The other problems were lack of technical know-how (79\%), irregular power supply $(78 \%)$, higher initial investment (68\%), smaller holdings (37\%) and duplication of seeds $(20 \%)$.

Table 1.2 Problems in papaya production

\begin{tabular}{|c|l|c|c|}
\hline SL. No & Particulars & Number of farmers (100) & Percent \\
\hline 1 & Due to virus attack & 100 & 100 \\
\hline 2 & Small holdings & 37 & 37 \\
\hline 3 & Labour intensive & 100 & 100 \\
\hline 4 & Water scarcity & 100 & 100 \\
\hline 5 & Higher initial investment & 68 & 68 \\
\hline 6 & Duplication of seeds & 20 & 20 \\
\hline 7 & Power supply & 37 & 37 \\
\hline 8 & Technical know how & 79 & 79 \\
\hline
\end{tabular}

Source: Primary Data 2013

\subsubsection{Problems of Papaya Marketing}

From the Table 1.3 it could be seen that all the respondents opined that markets far away from the farm, over 82 per cent of the respondents opined that higher commission charges was another major problem in 
marketing of papaya. The other problems were lack of availability of market information (79\%), storage problem (76\%), price fluctuations (37\%) and lack of skilled labour for packing $(19 \%)$.

Table 1.3 Problems in papaya Marketing

\begin{tabular}{|c|l|c|c|}
\hline $\begin{array}{c}\text { SL. } \\
\text { No }\end{array}$ & Particulars & Number of farmers (100) & Percent \\
\hline 1 & Markets far away from farm & 100 & 100 \\
\hline 2 & Storage problem & 76 & 76 \\
\hline 3 & Price fluctuations & 37 & 37 \\
\hline 4 & High commission & 82 & 82 \\
\hline 5 & $\begin{array}{l}\text { Lack of availability of market } \\
\text { information }\end{array}$ & 79 & 19 \\
\hline 6 & $\begin{array}{l}\text { Lack of skilled labour for } \\
\text { packing }\end{array}$ & 19 & \\
\hline
\end{tabular}

Source: Primary Data 2013

\section{Discussion}

\subsection{Growth Rates in Area, Production and Productivity in Papaya Farming}

The compound growth rate of area, production and productivity of papaya is presented in Table 1.1 are discussed below.

A highly positive and significant growth in area and production of papaya crop was observed and Bidar district. This high growth rate in area and production is because of the Gulbarga drastic increase in the area under the papaya cultivation. This clearly indicated the increasing popularity of this crop in the study area especially in Gulbarga district. Whereas while the productivity is concerned, the growth rate is negative in Bidar district because of decline in the yield in these district during the years. Further it could be seen from the table that the growth rate for state as a whole was considered indicated the positive growth rate in area and production, negative growth rate in case of productivity in Bidar district. The negative growth rate in production and productivity is because of the constraints like virus attack and scarcity of water during the recent years.

\subsection{Problems in Production and Marketing of Papaya}

The problems faced by the producers of papaya are presented in the (Table 1.2) have been briefly discussed as follows:

\subsubsection{Problems of production}

All the papaya growers in study area expressed the problems of virus attack, labour intensiveness and water scarcity. As far as virus attack was considered the use of plant protection chemicals was in excess of the requirements as it was seen from the earlier pages. This is due to imperfect knowledge about the viral disease. Next as the papaya is an labour oriented crop there is problem of availability of the labour at the peak time of harvesting or some time of the other operations. As the crop is water intensive crop and there was drought during last year so availability of water was one of the major problem in production of papaya. About 79 per cent of the respondents expressed that the non-availability of the technical aspects know how for the improved papaya cultivation in the study area. And about 68 per cent of the farmers opinioned that the enterprise require higher initial investment which the small farmer can't provide an they faced problems in getting credit facilities from institutional agencies. Other constraints in papaya production are irregular power supply and smaller holding 37 per cent each and duplication of seeds 20 per cent.

\subsubsection{Problem in marketing}

The problems faced by the farmer in marketing of papaya were presented in the table (Table 1.3) have been briefly discussed below.

The entire sample farmers opined problem regarding the transportation viz., poor road conditions, lower frequencies of vehicles for transportation, minimum of 5-6 tonnes is must for the economic transportation. Majority of the farmers (82\%) expressed high commission charges as the one of the major problem in marketing. The commission agents charged 10 per cent of the commission from the producer, which ultimately reduces the producer's net price.

Another major problem was lack of availability of market information as it was opined by 79 per cent of the respondents. The latest market information is not available to the producer and he will not knowabout daily price fluctuations in the market. Further as indicated by the table it could be seen that storage is also one of the major problem in marketing of papaya as it was expressed by 76 per cent of the farmers. As there is no adequate storage facility for the fruit the farmer has to sell the produce as soon as possible before it get spoiled. Due to this reason the farmer some times are forced to sell the produce at lower price. Other marketing problems were price fluctuations 37 per cent and lack of skilled laborers for packing 19 per cent. 


\section{Findings and policy implications:}

1. The growth rate analysis for area, production and productivity of papaya in Bidar, Gulbarga and state as a whole revealed that there was positive and highly significant growth rates in area and production in both the district. On the contrary the productivity was negative in both of the districts. And as state as a whole there was positive growth rate with respect to area. While the production and productivity were negative.

2. Opinion survey was conducted to know the problems faced by papaya growers in production and marketing. All the farmers expressed that virus attack non-availability of labour and water scarcity was major problems in papaya production followed by non-availability of technical guidance $(79 \%)$ and higher initial investment (68\%). Distant markets (100\%), high commission charges (82\%), lack of availability of market information $(79 \%)$ and storage problem (76\%) were the major problem faced by the papaya growers in marketing of papaya.

\section{Policy Implications:}

Major policy implications based on the findings of the study are summarized below:

1. The growth rate analysis indicated that the increase in production was due to area, rather than productivity, which calls for intensive efforts to increase productivity of papaya in the study area.

2. All the farmers expressed the incidence of virus attack as a major problem, the gravity of which has increased due to lack of technical guidance. Hence, there is an urgent need to evolve an integrated pest management programmed besides strengthening the extension system in imparting knowledge about prevention and control of virus attack to papaya.

\section{Conclusion}

Papaya is considered one of the most important fruits because it is a rich source of antioxidant nutrients (e.g., carotenes, vitamin C, and flavonoids), the B vitamins (e.g., folate and pantothenic acid), minerals (e.g., potassium and magnesium), and fiber. In addition, papaya is a source of the digestive enzyme papain, which is used as an industrial ingredient in brewing, meat tenderizing, pharmaceuticals, beauty products, and cosmetics. Production in India has increased significantly within the last few years, and is chiefly responsible for the noticeable growth in global papaya production. The second major problem faced by the global papaya industry is significant post-harvest losses along the marketing chain. Factors such as fungal diseases, physiological disorders, mechanical damage, or a combination of these are the leading causes of post-harvest losses. While papaya has suffered post-harvest losses ranging from 30 to 60 percent in the Southeast Asia region (FAO 2006), simple technology and practices have helped to reduce losses and to extend storage life. The major post-harvest constraint, however, is infrastructure development, with challenges such as needed improvements in road access to the producing regions and insufficient electricity supply when demand continues to grow also being of concern for this industry and its stakeholders.

\section{References}

[1]. Singh, I.D., 1990, Papaya, Mohan Primlani for Oxford and IBH Publishing Company, New Delhi.

[2]. Venkateshwarlu, M., Raju, V.J. and Naidu, M.R., 1998, Growth and productivity of banana in Andhra Pradesh. South Indian Horticulture, $36(4): 163-166$.

[3]. Sundaravaradarajan, K.R. and Jahanmohan, K.R., 2002, Marketing cost, margin, price spread and marketing efficiency of cashew in Tamil Nadu.Agricultural Situation in India, 59 (1) : 9-16.

[4]. Subrahmanyam, K.V., 1986, Profitable lime cultivation in Andhra Pradesh.Indian Horticulture,31 :5-6.

[5]. Patil, T.Y., Hinge, B.J. and Rajamani, K.D., 1969, Economic problems of horticultural plantations in Maharashtra. Indian Journal of Agricultural Economics, 24 (4) : 249- 255.

[6]. Khunt, K.A., Gajipara, H.M., Gadhvi, B.K. and Vekariya, S.B., 2001, Economics of production and marketing of pomogranate.Indian Journal of Agricultural Marketing, 17 (1) : 100-107. 